University of Wollongong

Research Online

Australian Institute for Innovative Materials -

Papers

Australian Institute for Innovative Materials

$1-1-2019$

Effect of monophasic pulsed stimulation on live single cell de-adhesion on conducting polymers with adsorbed fibronectin as revealed by single cell force spectroscopy

Hongrui Zhang

University of Wollongong, hz215@uowmail.edu.au

Gordon G. Wallace

University of Wollongong, gwallace@uow.edu.au

Michael J. Higgins

University of Wollongong, mhiggins@uow.edu.au

Follow this and additional works at: https://ro.uow.edu.au/aiimpapers

Part of the Engineering Commons, and the Physical Sciences and Mathematics Commons

Research Online is the open access institutional repository for the University of Wollongong. For further information contact the UOW Library: research-pubs@uow.edu.au 


\title{
Effect of monophasic pulsed stimulation on live single cell de-adhesion on conducting polymers with adsorbed fibronectin as revealed by single cell force spectroscopy
}

\begin{abstract}
The force required to detach a single fibroblast cell in contact with the conducting polymer, polypyrrole doped with dodecylbenzene, was quantified using the Atomic Force Microscope-based technique, Single Cell Force Spectroscopy. The de-adhesion force for a single cell was $0.64 \pm 0.03 \mathrm{nN}$ and predominately due to unbinding of $\alpha 5 \beta 1$ integrin complexes with surface adsorbed fibronectin, as confirmed by blocking experiments using antibodies. Monophasic pulsed stimulation ( $50 \mu \mathrm{s}$ pulse duration) superimposed on either an applied oxidation $(+500)$ or reduction $(-500 \mathrm{mV})$ constant voltage caused a significant decrease in the de-adhesion force by $30 \%-45 \%$ to values ranging from 0.34 to $0.43 \mathrm{nN}( \pm 0.02 \mathrm{nN})$. The electrical stimulation caused a reduction in the molecular-level jump and plateau interactions, while an opposing increase in nonspecific interactions was observed during the cell de-adhesion process. Due to the monophasic pulsed stimulation, there is an apparent change or weakening of the cell membrane properties, which is suggested to play a role in reducing the cell de-adhesion. Based on this study, pulsed stimulation with optimized threshold parameters represents a possible approach to tune cell interactions and adhesion on conducting polymers.

Disciplines

Engineering | Physical Sciences and Mathematics

\section{Publication Details}

Zhang, H., Wallace, G. G. \& Higgins, M. J. (2019). Effect of monophasic pulsed stimulation on live single cell de-adhesion on conducting polymers with adsorbed fibronectin as revealed by single cell force spectroscopy. Biointerphases: an open access journal for the biomaterials interface community, 14 (2), 021003-1-021003-11.
\end{abstract}




\section{Effect of monophasic pulsed stimulation on live single cell de-adhesion on conducting polymers with adsorbed fibronectin as revealed by single cell force spectroscopy}

Hongrui Zhang, Gordon G. Wallace, and Michael J. Higgins

Citation: Biointerphases 14, 021003 (2019); doi: 10.1116/1.5082204

View online: https://doi.org/10.1116/1.5082204

View Table of Contents: https://avs.scitation.org/toc/bip/14/2

Published by the American Vacuum Society

\section{ARTICLES YOU MAY BE INTERESTED IN}

Effect of electrochemical oxidation and reduction on cell de-adhesion at the conducting polymer-live cell interface as revealed by single cell force spectroscopy

Biointerphases 13, 041004 (2018); https://doi.org/10.1116/1.5022713

Repeatability, Reproducibility, and Replicability: Tackling the 3R challenge in biointerface science and engineering

Biointerphases 14, 020201 (2019); https://doi.org/10.1116/1.5093621

Cytoskeletal synchronization of $\mathrm{CHO}$ cells with polymer functionalized fullerene $\mathrm{C}_{60}$

Biointerphases 14, 021002 (2019); https://doi.org/10.1116/1.5084002

Advances in materials for cellular applications (Review)

Biointerphases 14, 010801 (2019); https://doi.org/10.1116/1.5083803

Loading the dice: The orientation of virus-like particles adsorbed on titanate assisted organosilanized surfaces

Biointerphases 14, 011001 (2019); https://doi.org/10.1116/1.5077010

Effect of the nonspecific binding in differential impedance biosensing

Biointerphases 14, 011004 (2019); https://doi.org/10.1116/1.5082717

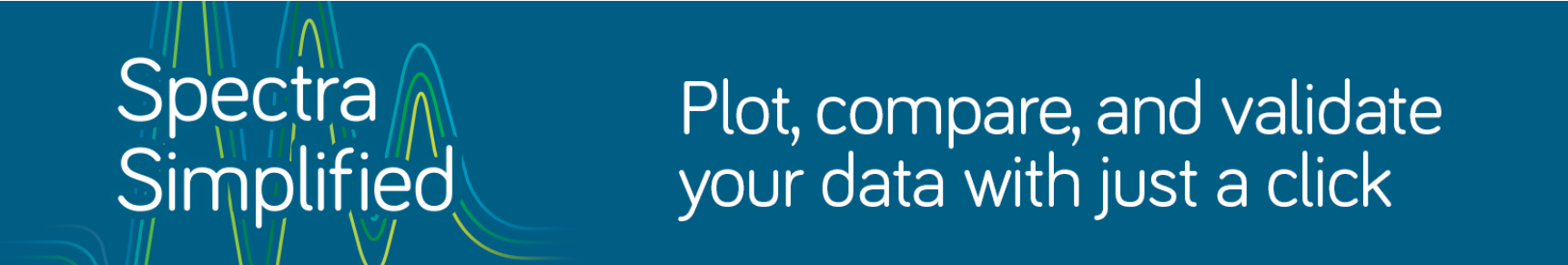




\title{
Effect of monophasic pulsed stimulation on live single cell de-adhesion on conducting polymers with adsorbed fibronectin as revealed by single cell force spectroscopy
}

\author{
Hongrui Zhang, Gordon G. Wallace, and Michael J. Higgins ${ }^{a)}$ \\ ARC Centre of Excellence for Electromaterials Science, Intelligent Polymer Research Institute, AIIM Facility, \\ Innovation Campus, University of Wollongong, Wollongong, NSW 2522, Australia
}

(Received 19 November 2018; accepted 5 March 2019; published 29 March 2019)

\begin{abstract}
The force required to detach a single fibroblast cell in contact with the conducting polymer, polypyrrole doped with dodecylbenzene, was quantified using the Atomic Force Microscope-based technique, Single Cell Force Spectroscopy. The de-adhesion force for a single cell was $0.64 \pm 0.03 \mathrm{nN}$ and predominately due to unbinding of $\alpha 5 \beta 1$ integrin complexes with surface adsorbed fibronectin, as confirmed by blocking experiments using antibodies. Monophasic pulsed stimulation (50 $\mu$ s pulse duration) superimposed on either an applied oxidation $(+500)$ or reduction $(-500 \mathrm{mV})$ constant voltage caused a significant decrease in the de-adhesion force by $30 \%-45 \%$ to values ranging from 0.34 to $0.43 \mathrm{nN}( \pm 0.02 \mathrm{nN})$. The electrical stimulation caused a reduction in the molecular-level jump and plateau interactions, while an opposing increase in nonspecific interactions was observed during the cell de-adhesion process. Due to the monophasic pulsed stimulation, there is an apparent change or weakening of the cell membrane properties, which is suggested to play a role in reducing the cell de-adhesion. Based on this study, pulsed stimulation with optimized threshold parameters represents a possible approach to tune cell interactions and adhesion on conducting polymers. Published by the AVS. https://doi.org/10.1116/1.5082204
\end{abstract}

\section{INTRODUCTION}

Many studies on conducting polymers have used constant potentials to switch between oxidized and reduced states, primarily inducing changes in surface chemistry, with the intention of controlling cell adhesion, growth, and differentiation for applications such as electronic cell culture systems and tissue regeneration. ${ }^{1-8}$ Studies also employ alternating current (AC) electrical stimulation, such as biphasic pulsed stimulation, to emulate the types of waveforms that are delivered by implantable electrode devices. ${ }^{9-14}$ Liu et al. investigated PC12 nerve cell differentiation on conducting polymers as a function of biphasic pulsed-current stimulation with frequencies of 10,100 , and $250 \mathrm{~Hz} .{ }^{11}$ They demonstrated that polypyrrole/poly (2-methoxy-5 aniline sulphonic acid (PPy/PMAS) supports nerve cell differentiation and that clinically relevant $250 \mathrm{~Hz}$ biphasic current pulses promoted nerve cell differentiation in the presence of nerve growth factor. Further work has shown that a higher proportion of human neural stem cells induced to Tuj1-expressing neurons and lower number of glial cells on laminin-coated PPy doped with dodecylbenzene sulfonate (PPy/DBSA) under biphasic pulsed-current stimulation compared to unstimulated PPy/ DBSA or glass substrates. ${ }^{12}$ The neural stem cells also exhibited a greater total neurite length per cell, mean neurite length, and maximum neurite length. ${ }^{12}$ The application of AC electrical stimulation using different types of electrode materials, such as composite hydroxyapatite (HA) and $\mathrm{BaTiO}_{3}$, have enhanced cell spreading and proliferation within a voltage and frequency range of $1-2 \mathrm{~V}$ at $100-150 \mathrm{~Hz}^{15}$

\footnotetext{
a) Author to whom correspondence should be addressed:
} mhiggins@uow.edu.a
The redox processes of conducting polymers, including switching of surface properties, become time-diffusion limited with increasing frequency of electrical stimulation. ${ }^{16}$ Therefore, the effects on cell adhesion, proliferation, and growth are expected to be less dependent on the switching of physical and chemical surface properties but instead more dependent on the capacitive charging and discharging directly at the electrode-cell interface. While most studies to date have focused on understanding the effects of oxidation and reduction of conducting polymers on cell adhesion, ${ }^{1-8}$ including changes in physical surface properties, ${ }^{17,18}$ density of adsorbed protein, and protein conformation, ${ }^{19-21}$ there has been a paucity of studies undertaken to investigate the frequency-dependent effects of electrical stimulation. In particular, pulsed stimulation can have effects on protein binding affinity, ${ }^{22}$ protein conformation, ${ }^{23}$ and cell membrane morphology, i.e., via electroporation. ${ }^{24}$

Here, we study the effect of monophasic pulsed stimulation by implementing electrochemical-single cell force spectroscopy (EC-SCFS) to probe the interactions of single live cells on the conducting polymer, PPy/DBSA, with adsorbed fibronectin (FN). We refer to previous SCFS studies as background for applying this technique to study cell adhesion, ${ }^{25,26}$ including single cell receptor-extracellular matrix protein unbinding, ${ }^{26,27}$ cell-cell adhesion, ${ }^{28}$ and cell interactions with chemically functionalized surfaces and materials. ${ }^{29-32}$ Conventional approaches for observing cell adhesion, such as optical and fluorescent imaging of cells spreading or rounding up, are typically performed on cells that have established adhesion over longer time periods (e.g., in cell culture for $\sim 2 \mathrm{~h}$ up to days). In contrast, the SCFS enables measurement of cell adhesion on the order of seconds up to several tens of minutes. For example, SCFS revealed that single integrin bond complexes can form within 
seconds. ${ }^{33}$ Specific to this study, we previously used SCFS to understand molecular-level interactions of single fibroblast cells directly on PPy/DBSA (Ref. 32) and more recently via surface adsorbed FN on the same conducting polymer. ${ }^{34}$ In both studies, the single cell de-adhesion forces and energy were quantified during applying a constant potential to induce switching from oxidized to reduced states. Here, we implement the EC-SCFS by attaching a live cell on the end of an AFM probe to enable direct measurements of cell adhesion on the PPy/DBSA, which functions as the working electrode within an in situ electrochemical cell (Fig. 1). After bringing the cell into contact with the polymer, monophasic pulsed stimulation of varying frequency is applied to expose the cell-polymer interface to a series of transient current and voltage spikes. In doing so, we demonstrate that the pulsed stimulation has significant effects on the single cell de-adhesion.

\section{METHODS}

\section{A. Electrochemical polymerization of conducting polymer films}

The aqueous solution for electrochemical polymerization consisted of $0.2 \mathrm{M}$ pyrrole monomer (Merck) and $2 \mathrm{mg} \mathrm{ml}^{-1}$
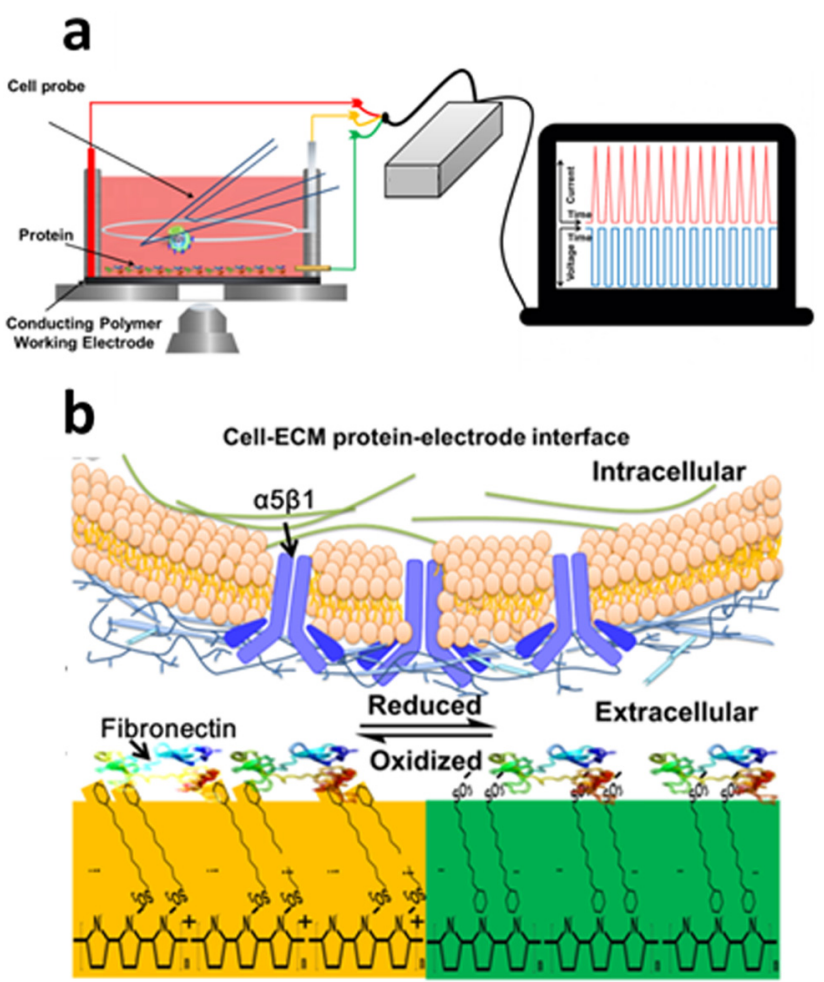

FIG. 1. (a) Schematic of SCFS combined with Electrochemical-Atomic Force Microscopy to quantify single live cell de-adhesion on a conducting polymer PPy/DBSA with adsorbed protein as a function of monophasic pulse stimulation. The three-electrode electrochemical cell is filled with $\mathrm{CO}_{2}$ independent cell culture medium and controlled at $37^{\circ} \mathrm{C}$, with the conducting polymer film as the working electrode, platinum ring as the counter electrode, and $\mathrm{Ag} / \mathrm{AgCl}$ reference electrode. (b) Zoomed in region of conducting polymer-cell interface. During the SCFS experiment, the PPy-DBSA electrode is electrochemically switched to either the oxidized (yellow) and reduced (green) states, causing reorientation of the DBSA. sodium DBSA in milli-q water (18.2 M $\Omega$ ). PPy films doped with DBSA were polymerized galvanostatically under 0.10 $\mathrm{mA} \mathrm{cm}{ }^{-2}$ for $10 \mathrm{~min}$ via an eDAQ EA161 potentiostat and recorder. The electrodeposition process was performed in a three-electrode JPK electrochemical-cell with gold mylar as the working electrode (growing area $2 \mathrm{~cm}^{2}$ ), a platinum wire counter electrode, and $\mathrm{Ag} / \mathrm{AgCl}$ reference electrode (DRIREF-2SH, World Precision Instruments). After growth, the films were washed with milli-q water, gently dried with $\mathrm{N}_{2}$, and kept in a dry oven until use. Cyclic voltammograms were acquired using PPy/DBSA as the working electrode with a scan rate of $100 \mathrm{mV} \mathrm{s}^{-1}$ in $\mathrm{CO}_{2}$ independent cell culture medium. Electrochemical potentials were recorded versus $\mathrm{Ag} / \mathrm{AgCl}$ reference electrode (DRIREF-2SH, World Precision Instruments).

\section{B. Fibronectin adsorption on polymer}

Human plasma $\mathrm{FN}$ was purchased from Invitrogen (Australia) (33016-015) and reconstituted in distilled water at a concentration of $1.0 \mathrm{mg} / \mathrm{ml} .20 \mu 1$ aliquots were prepared into $2 \mathrm{ml}$ tubes and stored at $-80^{\circ} \mathrm{C}$ prior to use. A tube of FN was thawed and $1 \mathrm{ml}$ of phosphate-buffered saline (PBS) solution was added to give a final FN concentration of $20 \mu \mathrm{g} / \mathrm{ml}$. The FN solution was injected into the EC cell and allowed to adsorb onto the PPy/DBSA film for $30 \mathrm{~min}$. Following this, the film was removed, rinsed with milli-q water, and then placed back into EC cell as the working electrode for SCFS experiments.

\section{Cell culture}

Mouse fibroblast L929 cell lines were originally sourced from ATCC (CCL-1TM). L929 cells were cultured in Dulbecco's Modified Eagle's Medium (12800017, Life Technology) supplemented with $10 \%$ fetal bovine serum (10099141, Life Technology) and $3.7 \mathrm{~g} / \mathrm{l} \mathrm{NaHCO}_{3}$ (S5761, Sigma). Cells were cultured at $37^{\circ} \mathrm{C}$ in a humidified, $5 \%$ $\mathrm{CO}_{2}$ atmosphere (HERA cell 150, Thermo) and were subcultured every two days by splitting 1 into 10 after trypsinizing with $0.25 \%$ trypsin to achieve the desired cell density. Before the experiments, L929 cells were cultured to $90 \%-100 \%$ confluency of the cell culture flask. More specifically, the old medium was removed from the cell culture flask and then rinsed with $5 \mathrm{ml}$ PBS. To remove cells, trypsin $(0.25 \%$, $0.5 \mathrm{ml}$ ) was added and the cell culture flask stored in a humidified $37^{\circ} \mathrm{C}$ incubator for $1-2 \mathrm{~min} .5 \mathrm{ml}$ of fresh cell culture medium was then added to the flask and the cell suspension transferred to a $15 \mathrm{ml}$ centrifuge tube, centrifuged at $1500 \mathrm{rpm}$ for $5 \mathrm{~min}$, and the supernatant removed. Then, cells were resuspended in $1 \mathrm{ml}$ fresh culture medium and $0.5 \mathrm{ml}$ transferred to a T-25 flask containing $4.5 \mathrm{ml}$ prewarmed culture medium. This flask was kept for further experiments. $0.5 \mathrm{ml}$ of fresh medium was added to the remaining cell suspension in the centrifuge tube and then centrifuged again at $1500 \mathrm{rpm}$ for $5 \mathrm{~min}$. The supernatant was removed and the cells were resuspended in $1 \mathrm{ml} \mathrm{CO}$ independent cell culture medium (18045-088, Life Technology), which is 
capable of maintaining long-term $\mathrm{pH}$ stability under atmospheric $\mathrm{CO}_{2}(0.04 \%) .1 \mathrm{ml}$ of the cell suspension was then transferred to a fresh $4 \mathrm{ml} \mathrm{CO}_{2}$ independent cell culture medium into the $15 \mathrm{ml}$ tube. This $5 \mathrm{ml}$ cell suspension was then used for SCFS experiments.

\section{AFM probe calibration and functionalization with concanavalin-A}

AFM tipless probes (NP-O10 from Bruker) were first plasma cleaned for $20 \mathrm{~min}$ and then calibrated for their spring constant $(\sim 0.06 \mathrm{~N} / \mathrm{m})$ using the thermal noise method. Functionalized probes for attaching live single cells were prepared according to Wojcikiewicz et al. $^{35}$ The probes were incubated in $0.5 \mathrm{mg} / \mathrm{ml}$ biotin-BSA (bovine serum albumin, biotinamidocaproyl-labeled) (A6043, Sigma) for $12 \mathrm{~h}$ at $4{ }^{\circ} \mathrm{C}$. After rinsing with PBS (P5368, Sigma), the probes were incubated in $0.5 \mathrm{mg} / \mathrm{ml}$ streptavidin solution for $1 \mathrm{~h}$ at room temperature, followed by further rinsing with PBS. To enable covalent coupling of concanavalin-A (Con-A), the probes were finally incubated in biotin-Con-A (C2272, Sigma) for $1 \mathrm{~h}$ at room temperature and rinsed with $\mathrm{PBS}$. After functionalization, the probes could be stored at $4{ }^{\circ} \mathrm{C}$ for up to two weeks.

\section{E. Attaching a single live cell to the functionalized AFM probe}

L929 cells resuspended in $1 \mathrm{ml} \mathrm{CO}$ independent cell culture medium (18045-088, Life Technology) were injected into the JPK Nanowizard Bio-AFM electrochemical cell, which was maintained at $37^{\circ} \mathrm{C}$. Cells were allowed to settle onto the PPy/DBSA film with the adsorbed FN for only 5$10 \mathrm{~min}$ to ensure they did not spread and adhere to the surface. A Con-A functionalized AFM probe was lowered toward the surface and prior to attaching a cell, a force curve was performed to measure the sensitivity. Then, the probe was positioned over a cell and contact was made with a force of $1 \mathrm{nN}$ for $5 \mathrm{~s}$ followed by retraction of the probe with an attached cell. Visualization of both the cantilever and cell with the inverted microscope and control of the cell sample by a motorized stage with a step resolution of $\approx<0.5 \mu \mathrm{m}$ enabled precise positioning of a single cell at the end of the AFM cantilever. The cell was allowed to establish adhesion for 5-10 min on the Con-A functionalized cantilever prior to the SCFS measurements. This has previously been done for ensuring that cell adhesion to the cantilever is greater than adhesion to the opposing surface. ${ }^{35}$ The live cell probe was then repositioned over the polymer to perform SCFS curves.

\section{F. Electrochemical-single cell force spectroscopy}

SCFS was performed using a JPK Nanowizard II mounted on a fully automated inverted Nikon microscope, with the three-electrode electrochemical cell integrated onto the AFM sample stage. The instrument was enclosed in a cell incubation system for temperature and humidity control. The electrochemical cell also enabled local temperature control of the sample and consisted of a freshly grown PPy/DBSA polymer film as the working electrode, platinum wire counter electrode, and small $\mathrm{Ag} / \mathrm{AgCl}$ reference electrode. Electrochemical voltage and current signals were controlled via an Edaq potentiostat and recorder (eDAQ EA161).

After positioning the live cell probe above the polymer, 10 SCFS curves were first performed on the nonstimulated polymer without applying a potential. The live cell probe was then retracted for $50 \mu \mathrm{m}$, and a squared-waved pulsed stimulation was applied with a $500 \mathrm{mV}$ amplitude ranging from either 0 to $500 \mathrm{mV}$, or -500 to $-1000 \mathrm{mV}$, with varying frequencies of 1,10 , and $100 \mathrm{~Hz} .10$ cells were measured for both 0 to $500 \mathrm{mV}$ and -500 to $-1000 \mathrm{mV}$ waveforms, with 10 SCFS curves collected at each frequency.

\section{G. Integrin blocking experiment}

Anti-integrin $\alpha 5 \beta 1$ antibody (ab75472, Abcam) was aliquoted $(2 \mu \mathrm{l})$ into $2 \mathrm{ml}$ tubes and stored at $-80{ }^{\circ} \mathrm{C}$ prior to use. After pipetting out $1 \mathrm{ml}$ of the cell suspension, as described in Sec. II C, $1 \mathrm{ml}$ of cell suspension was injected into the aliquot of antibody. $1 \mathrm{ml}$ of the cell suspension with the anti-integrin $\alpha 5 \beta 1$ antibody was then transferred to a $15 \mathrm{ml}$ tube and $4 \mathrm{ml}$ of fresh $\mathrm{CO}_{2}$ independent medium was added. The $5 \mathrm{ml}$ cell suspension with antibody was kept at $37^{\circ} \mathrm{C}$ in an incubator for $30 \mathrm{~min}$ before injecting into the three-electrode electrochemical cell for the SCFS blocking experiments.

\section{H. Data analysis}

SCFS curves were analyzed using the JPK-SPM Data Processing software (version spm-5.1.4). The raw curves were first converted to force versus distance curves and then modified to adjust the baseline offset and arbitrary contact point. The software automated the measurement of the maximum de-adhesion force (maximum negative force value) and de-adhesion energy (integrated area under negative force region) and also enabled detection of the individual ruptures, including jumps and plateaus. Fit parameters for identifying and quantifying the jumps and plateaus were controlled by smoothing $(<4.0)$ and significance $(0.005)$ parameters, and their identification was subsequently confirmed by manual checking. More specifically, jumps were categorized as those ruptures with only negative slopes greater than $-20 \mathrm{pN} / \mu \mathrm{m}$, while plateaus with slopes in the positive region close to zero, i.e., $0-20 \mathrm{pN} / \mu \mathrm{m}$ were only considered for the analysis, according to a similar analysis done by Sariisik et al. ${ }^{36}$

Box-and-whisker plots of the maximum de-adhesion, de-adhesion energy, jump and plateau force, and length were plotted and fitted by OriginPro 9.1. All values were presented as mean \pm standard error of the mean. ANOVA and Mann-Whitney were performed using statistical packages of OriginPro 9.1 and Igor Pro (Wavemetrics).

\section{RESULTS}

\section{A. Electrical stimulation scheme}

The FN protein was first allowed to adsorb onto the PPy/ DBSA polymer electrode. The live cell probe was then 
brought into contact with the polymer surface (Fig. 1) and initial SCFS curves were performed without applying electrical stimulation (nonstimulated polymer). Subsequent SCFS curves were performed while applying monophasic pulsed stimulation with an amplitude of $500 \mathrm{mV}$ ranging from either 500 to $0 \mathrm{mV}$ (oxidized) or -500 to $-1000 \mathrm{mV}$ (reduced) at varying frequencies of 1,10 , and $100 \mathrm{~Hz}$. The monophasic pulsed stimulation waveforms, including the applied voltage (blue traces) and current (red traces), at the different frequencies are shown in Figs. 2(a)-2(f). During the pulses, the baseline voltage was held at $+500 \mathrm{mV}$ [Figs. 2(a), 2(c), and 2(e)] or $-500 \mathrm{mV}$ [Figs. 2(b), 2(d), and 2(f)] to maintain the oxidized and reduced state of the polymer.

In these waveforms, the pulse duration was kept very short with a constant value of $50 \mu \mathrm{s}$, while in comparison the pulse interval was significantly higher, on the order of seconds, and varied depending on the frequency. During a single SCFS curve, the cell approaches and is held in contact with the polymer surface for a $1 \mathrm{~s}$ dwell time, after which the cell is retracted by a distance of $50 \mu \mathrm{m}$. Therefore, when considering a dwell time of $1 \mathrm{~s}$ occurring with the lowest stimulation frequency of $1 \mathrm{~Hz}$ (pulsed interval of $\sim 1 \mathrm{~s}$ ), the cell "sees" a constant potential except for a possible transient change in voltage (50 $\mu$ s pulse duration) for only 1 cycle [Figs. 2(a) and 2(b)]. At $10 \mathrm{~Hz}$, the pulse interval decreases to $\sim 0.1 \mathrm{~s}$ and the cell is therefore subject to an increased number of transient voltage excursions of 10 cycles [Figs. 2(c) and 2(d)]. At $100 \mathrm{~Hz}$, the pulse interval is $\sim 0.01 \mathrm{~s}$ with 100 voltage excursions occurring during the dwell time of $1 \mathrm{~s}$ when the cell is in contact with the polymer surface [Figs. 2(e) and 2(f)].

However, the total length of time the cell is effectively in contact with the surface, including during the initial increase in loading force, dwell time (1 s), and subsequent adhesive interactions that extend for several micrometers, is $\sim 2-3 \mathrm{~s}$. Thus, transient voltage/current spikes occur at these various stages of cell contact with the polymer. The total time taken
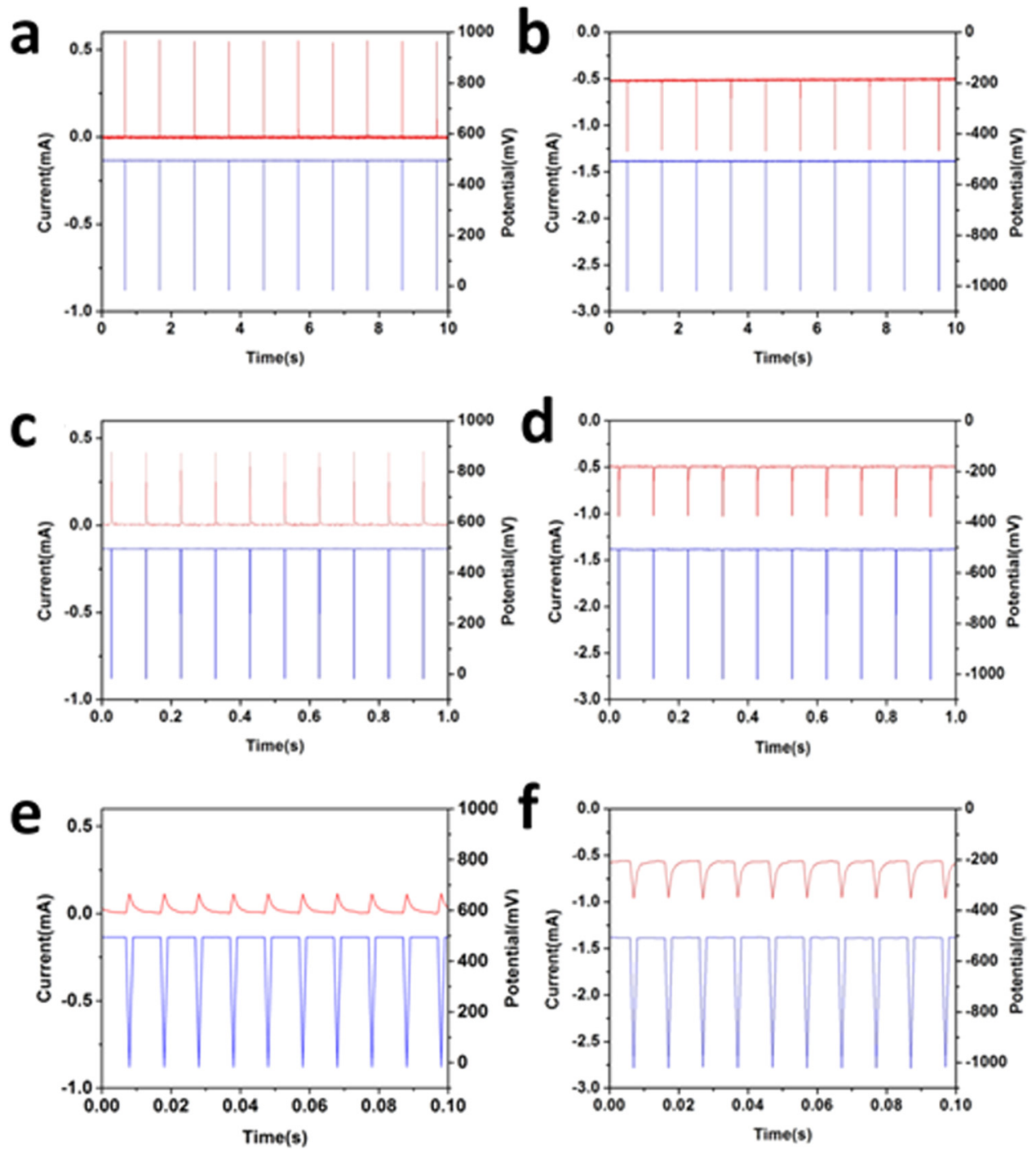

FIG. 2. Waveforms of monophasic pulsed stimulation of different frequencies with baseline voltages of either +500 or $-500 \mathrm{mV}[(\mathrm{a})-(\mathrm{f})]$. Current (red) and voltage (blue) vs time during application of pulsed stimulation with frequencies of $1 \mathrm{~Hz}$ (pulse interval $=1 \mathrm{~s}$, pulse duration $=0.05 \mathrm{~ms}$ ), $10 \mathrm{~Hz}$ ( pulse interval $=$ $0.1 \mathrm{~s}$, pulse duration $=0.05 \mathrm{~ms}$ ), and $100 \mathrm{~Hz}$ (pulse interval $=0.01 \mathrm{~s}$, pulse duration $=0.05 \mathrm{~ms}$ ) for baseline voltage of $+500 \mathrm{mV}(\mathrm{a}, \mathrm{c}$, and $\mathrm{e})$ and $-500 \mathrm{mV}$ (b, d, and f). 
to collect a single SCFS curve is $5 \mathrm{~s}$, i.e., $10 \mu \mathrm{m}$ z-distance at $5 \mu \mathrm{m} / \mathrm{s}$ gives $4 \mathrm{~s}$ with an additional $1 \mathrm{sec}$ dwell period. There is also a rest period of $10 \mathrm{~s}$ between each SCFS curve, with a total of 10 SCFS curves collected at each frequency. Therefore, the voltage/current spikes are occurring during periods when the cell is not in contact with the polymer. We note that while the same live cell probe is subject to different stimulation frequencies, their corresponding de-adhesion forces and energies represent a cumulative effect of the applied stimulation, specifically for 10 and $100 \mathrm{~Hz}$. For example, at the onset of $10 \mathrm{~Hz}$ stimulation, the cell has already been subject to a total of 150 pulses from the previous $1 \mathrm{~Hz}$ stimulation. Similarly, having completed the $10 \mathrm{~Hz}$ stimulation, the cell has been subject to cumulative $(150)+(150 \times 10)=1650$ pulses until being exposed to a cumulative total of $(150 \times 1 \mathrm{~Hz})+$ $(150 \times 10 \mathrm{~Hz})+(150 \times 100 \mathrm{~Hz})=16650$ pulses upon completion of $100 \mathrm{~Hz}$ stimulation.

The pulsed voltage for the $+500 \mathrm{mV}$ baseline, involving returning to $0 \mathrm{mV}$ and then back to the baseline, induced a sharp increase followed by a decay in the current with peak values of $0.5 \mathrm{~mA}(1 \mathrm{~Hz}), \quad 0.4 \mathrm{~mA}(10 \mathrm{~Hz})$, and $0.1 \mathrm{~mA}$ $(100 \mathrm{~Hz})$ [Figs. 2(a), 2(c), and 2(e)]. The pulsed voltage from the $-500 \mathrm{mV}$ baseline, involving a decrease to $-1000 \mathrm{mV}$ and then back to the baseline, similarly induced a peak in the current but in the opposite direction with values of $-0.75 \mathrm{~mA}$ $(1 \mathrm{~Hz}),-0.5 \mathrm{~mA}(10 \mathrm{~Hz})$, and $-0.3 \mathrm{~mA}(100 \mathrm{~Hz})$ (note: from a baseline current of $-0.5 \mathrm{~mA}$ ) [Figs. 2(b), 2(d), and 2(f)]. The peak value of the current signal decreased with an increase in frequency, as expected due to an increase in electrode impedance at higher frequencies. In addition, the peak current values generated with the $-500 \mathrm{mV}$ baseline are larger, which is in agreement with the higher current values at the reduction potentials reported in previous $\mathrm{CV}$ measurements. ${ }^{32}$ For instance, our previous studies using the same in situ electrochemical-AFM setup to acquire $\mathrm{CV}$ measurements on Pyy/DBSA in $\mathrm{CO}_{2}$ independent culture medium showed clear oxidation and reduction potentials of -340 and $-500 \mathrm{mV}$, respectively, when cycling the applied voltage from +0.5 to $-1.0 \mathrm{~V}$ (Ref. 32) It is also known, however, that the presence of an adsorbed protein layer decreases the capacitance, which can be accentuated by an increase in the electrode surface area or roughness, and also an increase in the thickness of the protein layer. ${ }^{37} \mathrm{~A}$ protein layer may block electron transfer between the electrode and electrochemical moieties in the solution, as demonstrated by cyclic voltammetry. ${ }^{37}$ In this study, we did not specifically investigate the effect of the adsorbed FN layer on the charge/discharge capacitance or impedance. Although in previous work ${ }^{32,34}$ and this study, monitoring of the current signal with adsorbed FN on the PPy/DBSA gave current outputs that were comparable to those used in chargebalanced biphasic stimulation $( \pm 1 \mathrm{~mA}){ }^{11,12}$

\section{B. Effect of pulsed stimulation on single cell de-adhesion}

Figure 3(a) displays the SCFS curves for the nonstimulated versus pulsed stimulation at different frequencies. Without an applied voltage, SCFS curves measuring the de-adhesion between a single L929 fibroblast cell and PPy/ DBSA with adsorbed FN shows hysteresis upon retraction of the cell from the surface, including a large peak related to the $\approx$ nanonewton forces required to detach most of the cell from the surface followed by smaller peaks and plateaus of $\approx<100 \mathrm{pN}$ [Fig. 3(a), black curve], previously defined as jumps

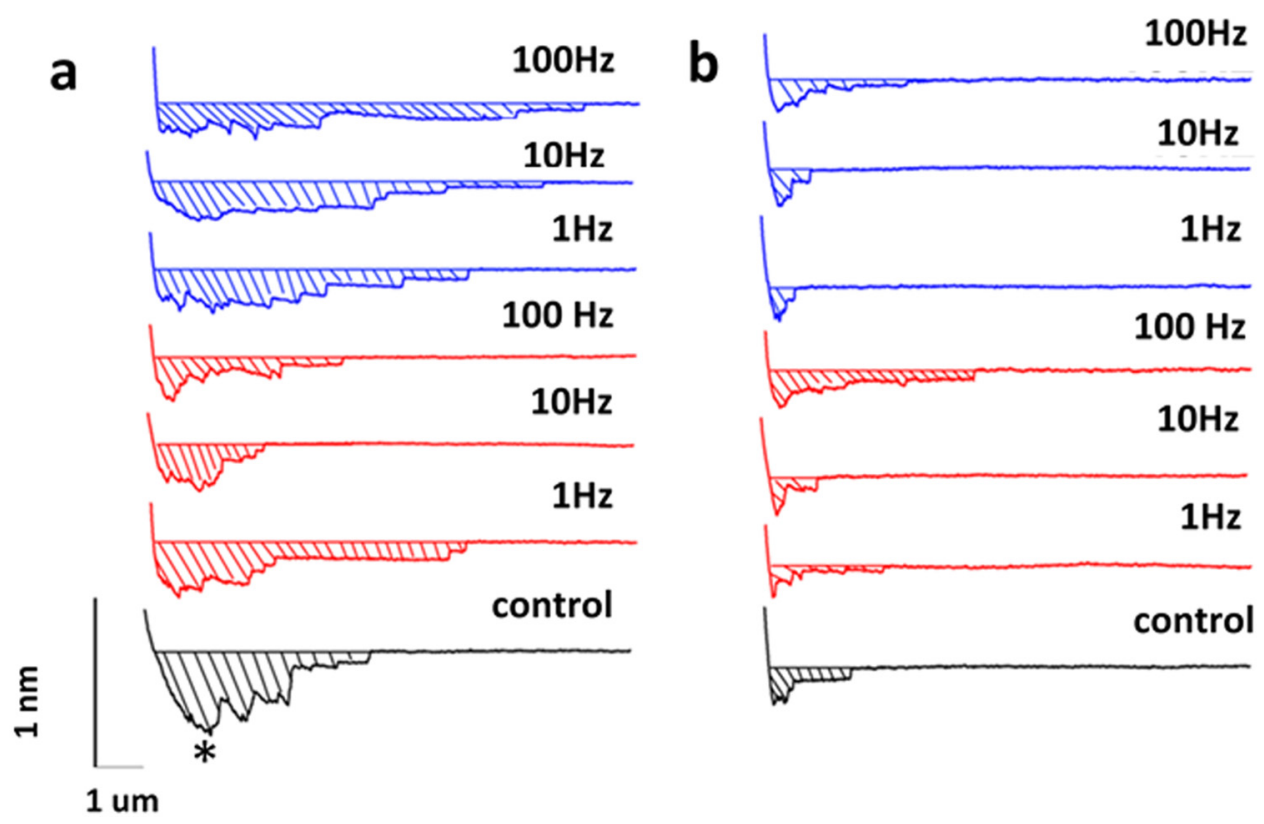

FIG. 3. (a) Representative SCFS curves of L929 fibroblast de-adhesion on PPy/DBSA for $+500 \mathrm{mV}$ (red) and $-500 \mathrm{mV}$ (blue) pulse stimulation at different frequencies and non-stimulated polymer (black, control). (b) Representative SCFS curves of blocking experiments using anti- $\alpha 5 \beta 1$ integrin antibodies to L929 fibroblast cells on PPy/DBSA for $+500 \mathrm{mV}$ (red) and $-500 \mathrm{mV}$ (blue) pulse stimulation at different frequencies and non-stimulated polymer (black, control). 
and tethers ${ }^{25,26}$ and associated with specific molecular interactions of the $\alpha 5 \beta 1$ integrin-FN complex. ${ }^{34}$ The peak maximum (asterisk) represents the maximum cell de-adhesion force required to fully detach the cell from the surface. Similarly, the adhesion energy can be calculated by integrating the area under the curves (striped area) in Fig. 3. Qualitative observations show that the maximum de-adhesion force and energy decreased for both the $+500 \mathrm{mV}$ (red curve) and $-500 \mathrm{mV}$ (blue curve) pulsed stimulation compared to the nonstimulated polymer (black curve). The monophasic pulsed stimulation also caused significantly longer-range adhesive interactions, including plateaus extending out to $\approx 5-7 \mu \mathrm{m}$, especially for the $-500 \mathrm{mV}$ baseline. Corresponding SCFS curves from blocking experiments, whereby anti- $\alpha 5 \beta 1$ integrin antibodies are introduced to the cells, significantly reduced the magnitude and distance-range of the peaks and plateau interactions under the same pulsed stimulation conditions [Fig. 3(b)], thus confirming the involvement of $\alpha 5 \beta 1$ integrin receptors in the cell de-adhesion.

Statistical analysis confirmed that the maximum de-adhesion force (left side box-whisker plots, red line) significantly decreased when a pulsed stimulation of either +500 [Fig. 4(a)] or $-500 \mathrm{mV}$ [Fig. 4(b)] was applied to the polymer, with the same effect occurring for the energy [Figs. 4(c) and 4(d)]. More specifically, nonstimulated polymers had a maximum de-adhesion force of $0.64 \pm 0.03 \mathrm{nN}$, which decreased by $33 \%-47 \%$ to values ranging from 0.34 to $0.43 \mathrm{nN}$ for pulsed stimulation at the different frequencies [Figs. 4(a) and 4(b)]. Similarly, the de-adhesion energy for the nonstimulated polymer $\left(13.9 \pm 0.8 \times 10^{-16} \mathrm{~J}\right)$ decreased by $\sim 30 \%-60 \%$ following pulsed stimulation [Figs. 4(c) and 4(d)]. Statistical significance was observed for all force and energy values between the nonstimulated polymer and the monophasic pulsed stimulation of both $\pm 500 \mathrm{mV}$ baselines.

The maximum de-adhesion force showed a decrease with cumulative pulsed stimulation at increasing frequencies and the same trend was observed for the energy (Fig. 4). For the $+500 \mathrm{mV}$ baseline, the maximum de-adhesion force gave values of $0.43 \pm 0.02 \mathrm{nN}(1 \mathrm{~Hz}), 0.40 \pm 0.01 \mathrm{nN}(10 \mathrm{~Hz})$, and $0.39 \pm 0.02 \mathrm{nN}(100 \mathrm{~Hz})$; however, no statistical difference was observed between the frequencies [Fig. 4(a)]. Corresponding de-adhesion energy showed a significant difference between $1 \mathrm{~Hz}\left(10.0 \pm 0.8 \times 10^{-16} \mathrm{~J}\right)$ and $100 \mathrm{~Hz}(7.7$ $\left.\pm 0.6 \times 10^{-16} \mathrm{~J}\right)$ [Fig. 4(c)]. Similarly, for the $-500 \mathrm{mV}$ baseline, the maximum de-adhesion force gave decreasing values of $0.39 \pm 0.01 \mathrm{nN}(1 \mathrm{~Hz}), 0.36 \pm 0.01 \mathrm{nN}(10 \mathrm{~Hz})$, and $0.34 \pm$ $0.01 \mathrm{nN}(100 \mathrm{~Hz})$, with a significant difference observed between 1 and $100 \mathrm{~Hz}$ [Fig. 4(b)]. For de-adhesion energy, significant differences were observed between all frequencies [Fig. 4(d)]. In summary, there was a significant loss in de-adhesion force and energy values after monophasic pulsed stimulation at $1 \mathrm{~Hz}$ (total 150 pulses). Subsequent cumulative effects of stimulation at $10 \mathrm{~Hz}(1650$ pulses $)$ and
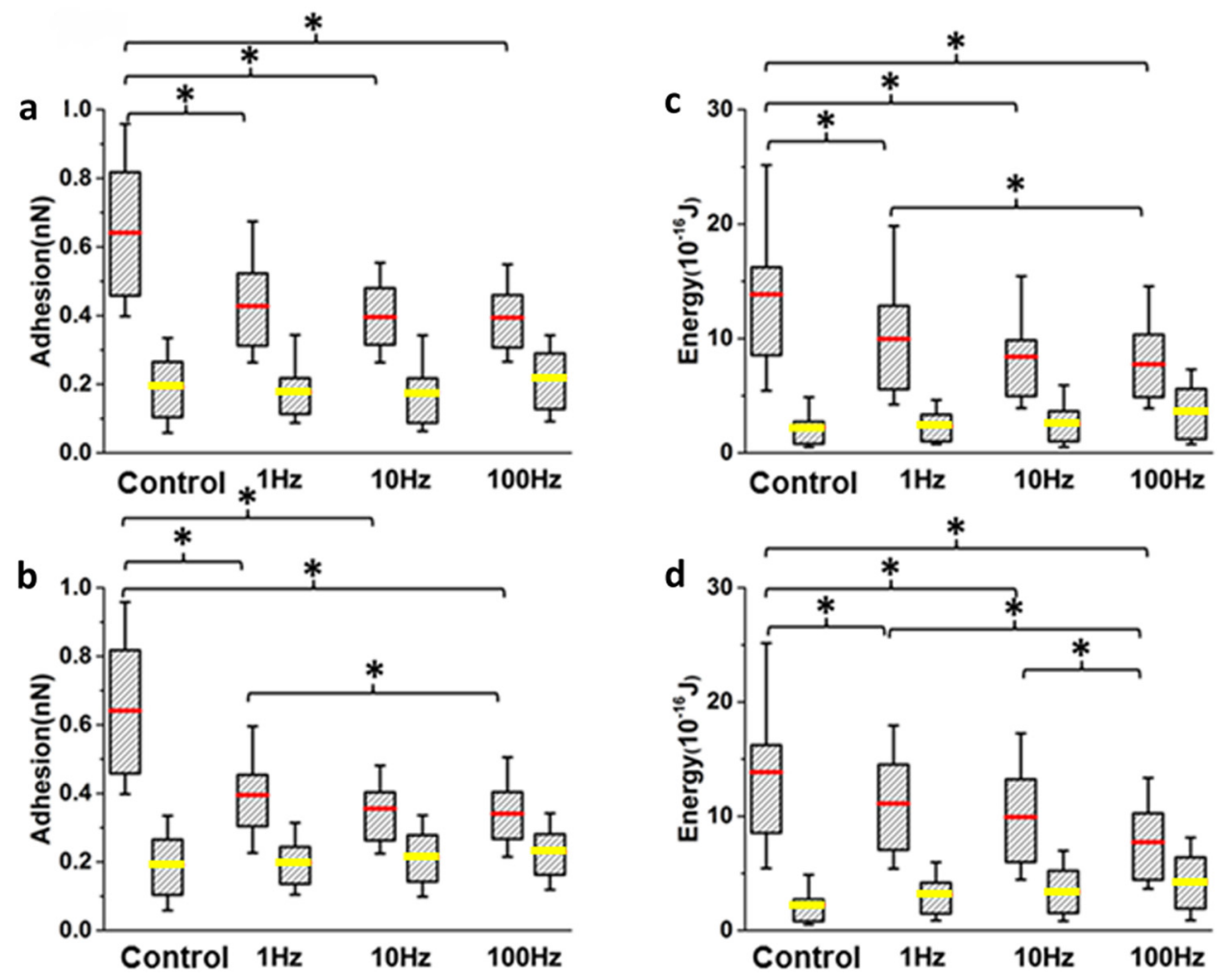

FIG. 4. Maximum de-adhesion forces for pulsed stimulation at different frequencies with $+500 \mathrm{mV}$ (a) and $-500 \mathrm{mv}$ (b) baseline voltages. Corresponding de-adhesion energy for pulsed stimulation at different frequencies for $+500 \mathrm{mV}$ (c) and $-500 \mathrm{mv}$ (d) baseline voltages. Box-whisker plots on the left-hand side with the red line are values from experiments without antibodies. Box-whisker plots on the right-hand side with the yellow line are values from blocking experiments with antibodies. The red and yellow line in box-whisker plots marks the mean values for non-blocking and blocking experiments with antibodies, respectively. Asterisks indicate statistical significance values of $p<0.05$ (Mann-Whitney). 
$100 \mathrm{~Hz}$ (16 650 pulses) caused an additional smaller, or statistically non-significant, decrease in de-adhesion, suggesting that the effect of the initial $1 \mathrm{~Hz}$ is the main determinant in reducing cell adhesion, i.e., as opposed to a loss in de-adhesion due to a cumulative effect of the pulsed stimulation.

Cell de-adhesion values from blocking experiments are shown in Fig. 4 (right side box-whisker plots, yellow line) and further elucidate the effect of pulsed stimulation on the cell de-adhesion. For the control samples, blocking with anti- $\alpha 5 \beta 1$ integrin antibodies caused a significant decrease in de-adhesion force and energy. Suppression of cell adhesion by the antibody blocking in SCFS is typically used to specify the involvement of receptors of interest. In this case, the integrin, $\alpha 5 \beta 1$, is considered to be a prototype receptor of FN, specialized for binding to $\mathrm{FN}$ via the tripeptide ArgGly-Asp and Pro-His-Ser-Arg-Asn regions, and one of the majorly expressed FN receptor across many cell types, including the L929 cell line. ${ }^{34}$ Despite confirming that the $\alpha 5 \beta 1$ integrin plays a predominant role in binding to the PPy/DBSA with surface adsorbed FN, the de-adhesion is not completely blocked, indicating remaining contributions from either those integrins that have not been blocked and/or nonspecific cell interactions with charged sites and surface groups of the PPy/DBSA. In contrast to SCFS without antibodies, the blocking de-adhesion forces and energies showed an opposing increase with cumulative pulsed stimulation, in particular with increasing frequency and especially evident in the de-adhesion energy values [Figs. 4(a)-4(d)]. This suggests that the number of non-specific interactions is increasing as the specific $\alpha 5 \beta 1$ integrin-FN unbinding is decreasing. For example, the non-specific de-adhesion forces account for $29 \%$ of the total adhesion on control samples, whereas in comparison $56 \%-67 \%$ of non-specific interactions account for the total adhesion on both $\pm 500 \mathrm{mV}$ pulsed stimulation at $100 \mathrm{~Hz}$. The corresponding contribution of non-specific interactions to the total energy at $100 \mathrm{~Hz}$ is $45 \%-55 \%$, which appears to be due to the longer-range peak and plateau interactions at the higher frequencies [Figs. 4(c) and 4(d)].

\section{Effects of pulsed stimulation on individual jump and plateau interactions}

Individual jumps and plateaus with forces of $\sim 50-75 \mathrm{pN}$ are indicative of single molecule unbinding forces, i.e., ligand-receptor complexes. ${ }^{25-27,29}$ Details on analysis of "jumps" and "plateaus" from the SCFS curves are given in Fig. S1. ${ }^{42}$ For the $+500 \mathrm{mV}$, the jump forces showed no significant difference between the control $(50.4 \pm 1.2 \mathrm{pN})$ and the pulsed stimulation, including no significant effect of the cumulative frequency $(1 \mathrm{~Hz}, 48.5 \pm 1.7 \mathrm{pN} ; 10 \mathrm{~Hz}$, $50.4 \pm 2.0 \mathrm{pN} ; 100 \mathrm{~Hz}, 47.1 \pm 1.9 \mathrm{pN}$ ) [Fig. 5(a)]. Conversely for $-500 \mathrm{mV}$, there was a significant decrease in the jump forces between the control and the pulsed stimulation, while significant differences were observed between $1 \mathrm{~Hz}$
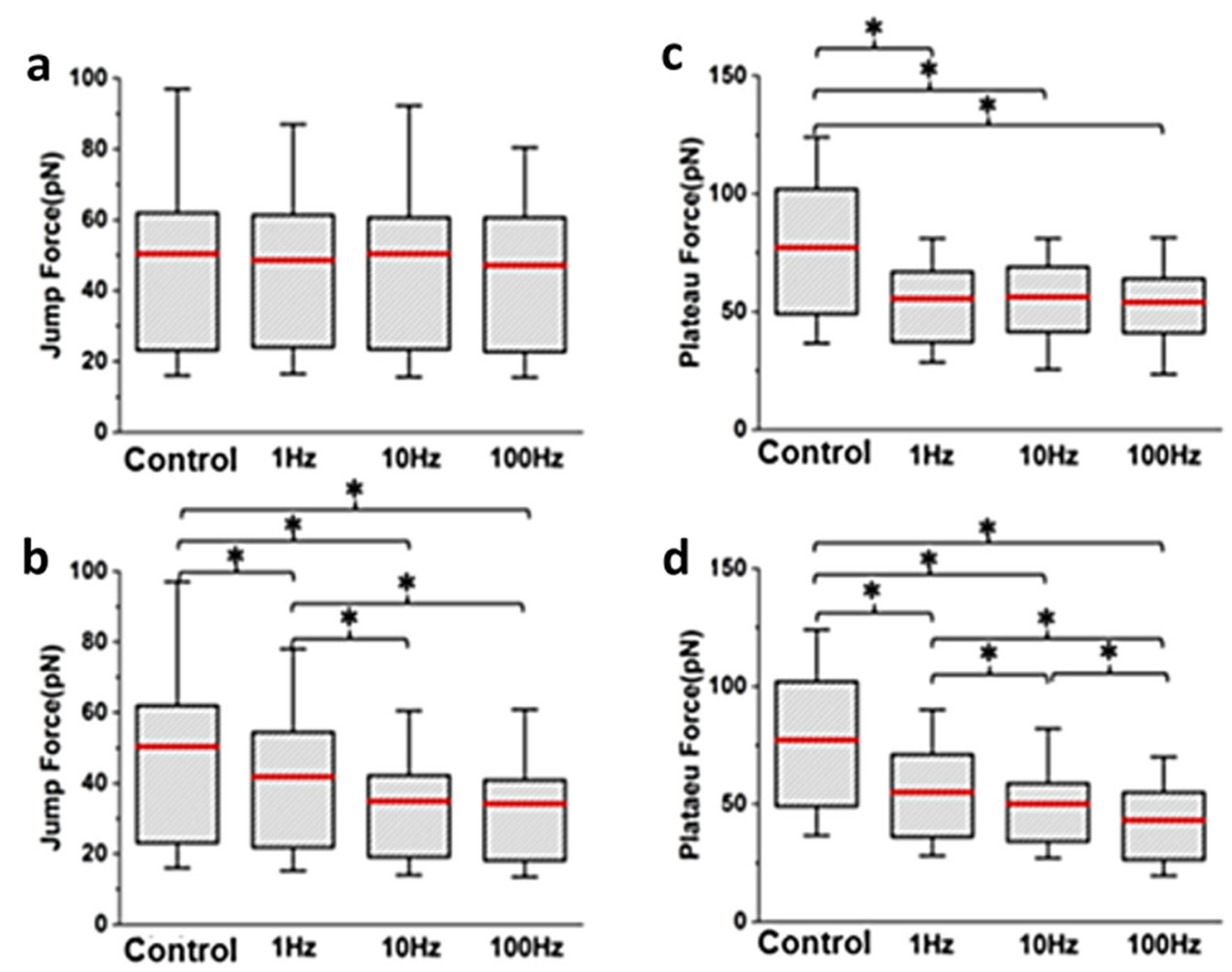

FIG. 5. Jump force for pulsed stimulation at different frequencies with $+500 \mathrm{mV}$ (a) and $-500 \mathrm{mv}$ (b) baseline voltages. Plateau force for pulsed stimulation at different frequencies with $+500 \mathrm{mV}$ (c) and $-500 \mathrm{mv}(\mathrm{d})$ baseline voltages. The red line in box-whisker plots marks the mean value. Asterisks indicate statistical significance values of $p<0.05$ (Mann-Whitney). 
$(41.8 \pm 1.0 \mathrm{pN})$ and the other two higher frequencies $(10 \mathrm{~Hz}$, $34.9 \pm 1.1 \mathrm{pN} ; \quad 100 \mathrm{~Hz}, \quad 34.2 \pm 1.2 \mathrm{pN}) \quad[$ Fig. $5(\mathrm{~b})]$. The plateau forces of the control $(77.1 \pm 3.2 \mathrm{pN})$ significantly decreased with pulsed stimulation for both $+500 \mathrm{mV}(\sim 55-$ $60 \mathrm{pN})$ and $-500 \mathrm{mV}(\sim 43-55 \mathrm{pN})$ [Figs. 5(c) and 5(d)] and clearly showed a linear dependence on the cumulative stimulation at the varying frequency for $-500 \mathrm{mV}$ [Fig. 5(d)]. These decreases in jump and plateau forces, with the exception of jumps for $+500 \mathrm{mV}$, were therefore in accordance with the deleterious effect on single cell de-adhesion from both \pm 500 pulsed stimulation.

In addition to jump/plateau forces, the changes in their interaction length can inform on the stiffness, elasticity, or ability of a tether to extend from the cell surface. ${ }^{38,39}$ For $+500 \mathrm{mV}$, there was no significant difference in the jump length for nonstimulated versus pulsed stimulation [Fig. 6(a)] but there was for the plateau length, which increased after pulsed stimulation [Fig. 6(c)]. $-500 \mathrm{mV}$ showed an increase in both jump [Fig. 6(b)] and plateau length [Fig. 6(d)], with a significant difference between nonstimulated and pulsed stimulation. Lastly, the observed number of jumps and plateaus in the SCFS curves showed that the total number of jumps per SCFS curve decreased with an increase in the cumulative frequency for both $+500 \mathrm{mV}$ [Fig. 7(a)] and $-500 \mathrm{mV}$ [Fig. 7(c)], indicating that pulsed stimulation reduced the number of molecular-level adhesion complexes to $10 \%-50 \%$ in comparison to the control. In contrast, the number of plateaus per SCFS curve was independent of frequency at $+500 \mathrm{mV}$ [Fig. 7(b)], while their number slightly increased with increasing frequency under $-500 \mathrm{mV}$ [Fig. 7(d)].

\section{DISCUSSION}

\section{A. Monophasic pulsed stimulation of oxidized and reduced polymer}

The monophasic potential waveforms applied in this study are different to pulsed stimulation commonly used in commercial implantable electrode devices, which use much shorter pulse durations (e.g., $0.1-10 \mathrm{~ms}$ ) and longer rest intervals (e.g., $\sim 20-100$ times greater than the duration). ${ }^{15}$ To emulate stimulation in these devices, previous studies using conducting polymers, ${ }^{11-14}$ including PPy/DBSA, ${ }^{12}$ have implemented biphasic constant current stimulation, with peak amplitudes of several milliamps. For example, these pulses generate voltage excursions (spikes) of several tens of $\mathrm{mV}$ at $\sim 250 \mathrm{~Hz} .{ }^{11}$ We adopted a different approach to enable a closer comparison with previous work using SCFS to quantify cell de-adhesion during an applied constant potential of +500 and $-500 \mathrm{mV} .{ }^{34}$ Hence, the baseline voltages were held at either +500 or $-500 \mathrm{mV}$ with longer pulse intervals relative to the duration such that the polymers were maintained at potentials associated with their oxidized and reduced states. The application of $\pm 500 \mathrm{mV}$ pulses then enabled current spikes to be superimposed on the electrically stimulated polymers in their redox state. At lower frequency $(1 \mathrm{~Hz})$, the cell was exposed to effectively a constant potential (i.e., oxidized and reduced polymers), while increasing the frequency to 10 and $100 \mathrm{~Hz}$ enabled investigation of an increasing number of current/voltage spikes during the SCFS. In doing so, the voltage pulses of $\pm 500 \mathrm{mV}$ were significantly larger, while the measured changes in current of $0.5-0.75 \mathrm{~mA}$ shown in Fig. 2 were close to the current generated from
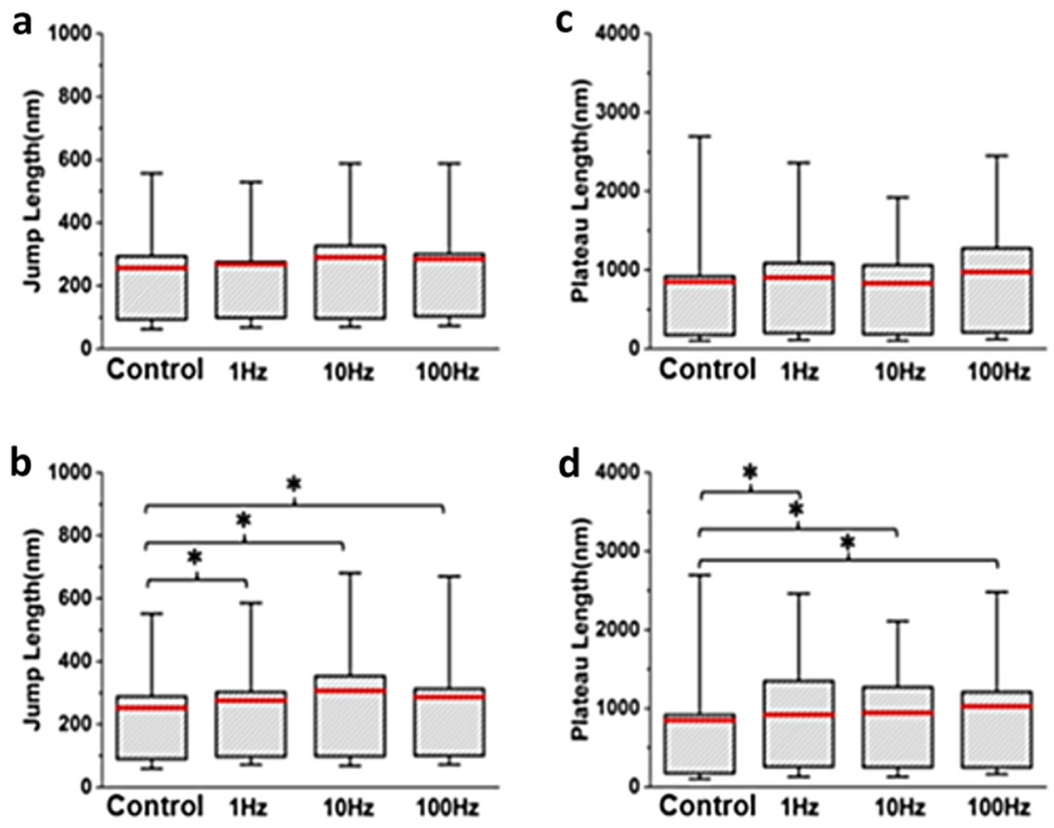

FIG. 6. Jump length for pulsed stimulation at different frequencies with $+500 \mathrm{mV}$ (a) and $-500 \mathrm{mv}$ (b) baseline voltages. Plateau length for pulsed stimulation at different frequencies with $+500 \mathrm{mV}$ (c) and $-500 \mathrm{mv}$ (d) baseline voltages. The red line in box-whisker plots marks the mean value. Asterisks indicate statistical significance values of $p<0.05$ (Mann-Whitney). 


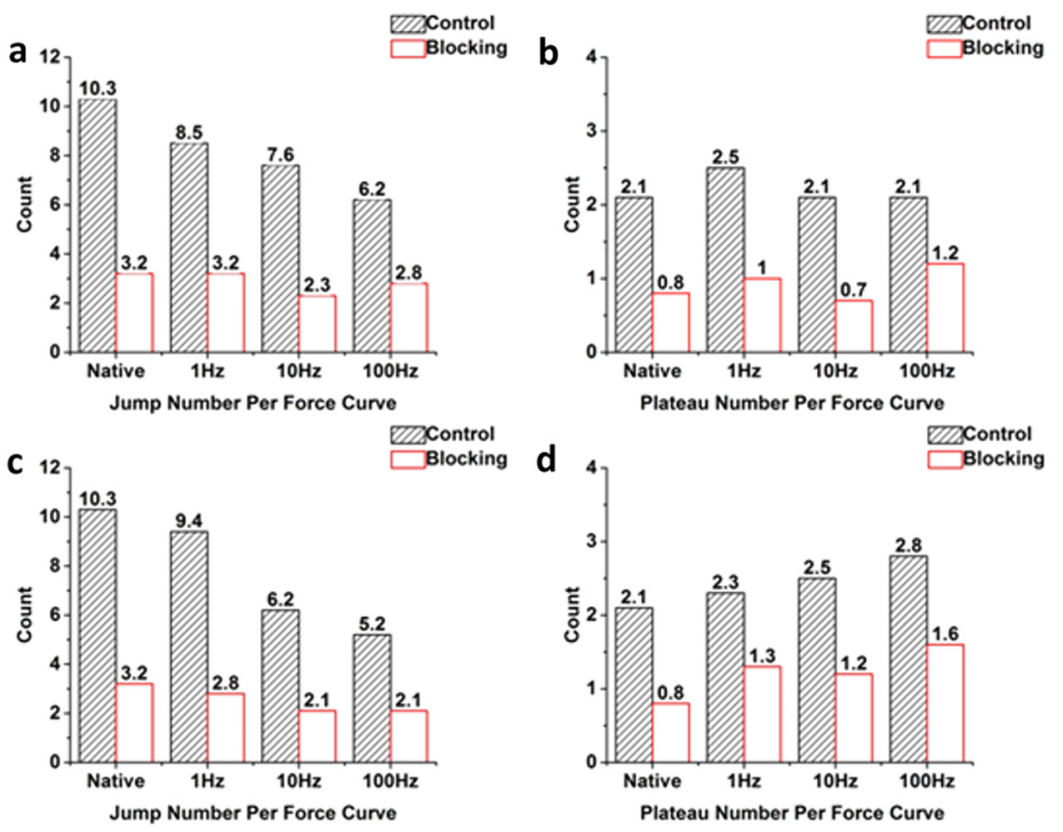

FIG. 7. Number of jumps per SCFS curve for pulsed stimulation at different frequencies with $+500 \mathrm{mV}$ (a) and $-500 \mathrm{mv}$ (c) baseline voltages. Number of plateaus per SCFS curve for pulsed stimulation at different frequencies with $+500 \mathrm{mV}$ (b) and $-500 \mathrm{mv}$ (d) baseline voltages. Black striped bars (control) are an analysis of SCFS experiments without blocking. Red bars are an analysis of SCFS experiments with blocking using antibodies.

biphasic stimulation used to induce effects on cells adhered to conducting polymers in previous studies. ${ }^{11,12}$

\section{B. Effect of electrical stimulation on interfacial redox properties}

To interpret the effects of electrical stimulation on the cell de-adhesion, we first explain the redox processes that provide the driving force for changes within the PPy/DBSA. Electrochemical switching of the PPy/DBSA polymer film is caused by the electrochemical doping and dedoping processes. Oxidation causes expulsion of positive $\mathrm{Na}^{+}$ions, upon which entrapped negatively charged sulfonate groups of the DBSA coordinate with positively charged PPy and the opposing benzene groups orientate to the polymer surface. Upon reduction, positive $\mathrm{Na}^{+}$ions enter the polymer for charge neutralization of the excess sulfonate groups. Benzene groups then switch back to coordinate with the neutral polymer, while excess sulfonate groups rearrange toward the polymer surface ${ }^{40}$ [Fig. 1(b)]. Typically, upon reduction of a polymer, the ejection of anions causes the polymer to contract. However, because $\mathrm{DBS}^{-}$is a large and immobile anion, solvated cations are incorporated to maintain charge neutrality, causing a significant increase in mass and associated uptake of solvent (water). ${ }^{18,32}$ The electrochemical processes are fully reversible and oxidation/reduction is achieved when applying constant potential or when undertaking $\mathrm{CV}$ measurements using scan rates in the range where ion-diffusion is not limited.

For monophasic pulsed stimulation at higher frequencies, the ability of ions to move in and out of the polymer becomes time-diffusion limited. At low frequency, ions have sufficient time to diffuse, entering the polymer and balancing charge; a process similar to applying a constant potential. At higher frequency, ions have less time to diffuse into the polymer and are predominately involved in surface charging (i.e., double layer formation). This frequency-dependent ion diffusion is evident from previous in situ EC-AFM studies on PPy with a similarly large, entrapped dopant, polystyrene sulfonate, that showed a significant nonlinear decay in the film expansion and contraction (actuation) during reduction and oxidation with increasing $\mathrm{CV}$ scan rate between 10 and $200 \mathrm{mV} / \mathrm{s}$, confirming the process of time-limited diffusion. ${ }^{16}$ In contrast, thinner films $<500 \mathrm{~nm}$ showed a decrease in actuation with increasing scan rate but this time with a linear relationship that was attributed to fast ion diffusion into the polymer, primarily occurring at the solid-liquid interface. ${ }^{16}$ Thus, the electrochemical actuation process shifted from a diffusion limiting to a current limiting system. Using the same EC-AFM approach, when a biphasic pulse $\pm 100 \mathrm{mV}$ was applied to differently doped PPy films, the actuation or ion diffusion into the polymer significantly diminished at $1 \mathrm{~Hz}$ and was effectively cutoff at $10 \mathrm{~Hz}{ }^{18}$ The PPy/DBSA films prepared in this work are polymerized with a low current density and charge, $0.1 \mathrm{~mA} \mathrm{~cm}^{-2}$ for $10 \mathrm{~min}$, resulting in very smooth films with thickness $<\sim 300 \mathrm{~nm} .^{16,32}$ Based on the above work, we expect that the thin PPy/DBSA films subject to the pulsed stimulation in this study exhibit similar electrochemical behavior, particularly rate-limiting processes of ion/current diffusion and primarily charging at the solid-liquid interface in the higher frequency range.

\section{Effect of constant versus pulsed potential stimulation on single cell de-adhesion}

Previous studies showed that epithelial cells adhered well to reduced poly(3,4-ethylenedioxythiophene) doped with 
tosylate (PEDOT/TOS) films while very few cells, mostly dead, remained on oxidized films when a constant bias voltage was applied immediately after cell seeding. ${ }^{8}$ The underlying cause of the cell viability on oxidized and reduced films was attributed to changes in the adsorbed serum layer, comprising mainly $\mathrm{FN}$ and other proteins. ${ }^{8}$ Earlier studies alluded to this mechanism by explaining the rounding-up and detachment of cells on oxidized PPy. ${ }^{1,2}$ However, other studies have since showed that oxidation of PEDOT/TOS conversely promoted the adhesion of mouse fibroblasts due to a higher affinity interaction between the $\alpha 5 \beta 1$ integrin and FN that was reportedly in a more folded conformation. ${ }^{4}$ Furthermore, along oxidized PEDOT:Tosylate electrodes, a relatively lower density of less tightly bonded, human serum albumin was observed compared to reduced electrodes, which was found to favor adhesion of the neural stem cells. ${ }^{7}$ Previous SCFS experiments directly confirmed that L929 fibroblast cells on PPy/DBSA were more strongly adhered during a constant oxidation potential of $+500 \mathrm{mV}(0.80 \pm 0.03 \mathrm{nN})$ compared to a reduction potential of $-500 \mathrm{mV}(0.56 \pm 0.02 \mathrm{nN})$ and non-stimulated polymer $(0.70 \pm 0.03 \mathrm{nN})$, with the de-adhesion energy values giving the same trend. ${ }^{34}$ By assuming the mass of adsorbed FN on the oxidized and reduced polymer surface remained equivalent, it was suggested that a constant potential modified the FN conformation, causing an increase in cell de-adhesion on the oxidized polymer and opposing decrease on the reduced polymer. ${ }^{34}$ In contrast for this study, the pulsed stimulation clearly had a deleterious effect on the cell de-adhesion for both the $\pm 500 \mathrm{mV}$ baseline potentials. After $1 \mathrm{~Hz}$ pulsed stimulation, where the cell was subject to a constant potential for effectively the total measurement time (i.e., 150 pulses at $50 \mu$ s duration were delivered during a total of $150 \mathrm{~s}$ ), the majority of cell de-adhesion force had been lost ( 30-40\%). Higher frequencies of 10 and $100 \mathrm{~Hz}$ resulted in subsequent smaller $\sim 5 \%$ decreases, indicating that the initial effects of the pulses, as opposed to their cumulative effect, had a stronger influence on the cell de-adhesion. Analysis of the molecular-level jumps and plateaus showed that their prevalence and forces mostly decreased for cumulative pulsed stimulation with increasing frequency. Since these types of interactions are predominately associated with $\alpha 5 \beta 1$ integrin-FN adhesion complexes, as revealed by blocking experiments, we suggest that the pulsed stimulation affects these adhesion complexes through modification to the FN adsorption or its conformation, and/or directly on the cell receptors, which is discussed further below. An increase in de-adhesion force and energy during blocking further suggests that the contribution of non-specific interactions increases while the integrin-FN complexes are diminished.

Possible mechanisms that explain the pulsed stimulation effects on cell adhesion may be gleaned by previous work on antibody-antigen interactions in PPy. ${ }^{22,41}$ In particular, pulsed stimulation between 400 and $-200 \mathrm{mV}$ of antibody-doped PPy allowed rabbit immunoglobulin ( $\operatorname{IgG}$ ) to reversibly bind to anti-rabbit IgG antibodies (RIgG). ${ }^{22}$ The extent of IgG-RIgG binding was modulated by applying positive $(+400 \mathrm{mV}$ versus $\mathrm{Ag} / \mathrm{AgCl})$ pulses for $200 \mathrm{~ms}$ to facilitate IgG-RIgG binding. The reversibility of antigen binding in antibody-doped PPy was attributed to the minimization of strong binding interactions by quickly switching between binding and dissociation states. By using $200 \mathrm{~ms}$ pulses, initial weaker van der Waals interactions could proceed but secondary, stronger hydrophobic binding forces stabilizing the antibody-antigen complex were minimized. Specifically related to FN, the binding between PPy doped with anti-FN antibody, specific to type III 9 and 10 cell binding regions, and free $\mathrm{FN}$ in the electrolyte showed that $200 \mathrm{~ms}$ pulses were too short a time period for significant FN binding to occur in the PPy matrix. ${ }^{41}$ The time scale for binding to occur was $>500 \mathrm{~ms}$ and at low frequencies $(2 \mathrm{~Hz}$ or less). Contrary to previous measurements, it was suggested that the reversibility of FN binding was not due to the minimization of secondary, stronger antibody-antigen binding forces but rather due to minimization of free charges in the PPy during oxidation and reduction. ${ }^{41}$ By interacting with $\mathrm{Na}+$ ions and $\mathrm{FN}$ at the PPy-electrolyte interface, the antibody-doped PPy was able to maintain charge neutrality by enhancing or impeding various electrochemical interactions. The above findings demonstrate the use of pulsed stimulation at higher frequencies for suppressing molecular binding at the conducting polymerelectrolyte interface, presumably due to either charge minimization effects within the polymer or by impeding affinity of the ligand-receptor complexes. Furthermore, electrochemical processes are localized in the vicinity of the adsorbed FN (e.g., within the double-layer) where significant effects can be exerted on the protein layer. Previous studies show that oscillating electrical fields induce electrophoretic-related frictional dissipative effects, causing unfolding of proteins such as BSA and lysozyme. ${ }^{23}$ The AC electrical fields modified the peptide conformations, forming beta sheets to alpha helices, through disruption of hydrogen bonding. Lastly, we note that $\pm 500 \mathrm{mV}$ pulsed stimulation is analogous to electroporation procedures that use high-voltage pulses to introduce DNA into most cell types for gene transfer and transfection. ${ }^{24}$ Two parameters that are critical for successful in vitro electroporation are the maximum voltage of the shock and duration of the current pulse. For skin cells, successful parameters of maximum $100 \mathrm{~V} / \mathrm{cm}$ field strength with the delivery of 8 pulses at $150 \mathrm{~ms}$ duration have been applied. ${ }^{24}$ High voltages are used as they are being applied across large distances, so the resulting field across the actual membrane is only a small fraction of the applied bias. Therefore, pulse thresholds of $0.5-1 \mathrm{~V}$ enable the electroporation mechanism, which first involves charging of the membrane through the migration of ions from the surrounding solution, followed by rapid localized rearrangement in lipid morphology of the cell membrane.

\section{CONCLUSIONS}

In conclusion, pulsed stimulation significantly decreased the single cell de-adhesion and energy. Most of the cell adhesion is already lost at the lowest frequency of $1 \mathrm{~Hz}$, suggesting that the immediate action of a pulse, as opposed to their cumulative effects, plays a role in exerting significant effects on the cell de-adhesion. As a result, the molecular-level 
interaction forces of the jumps and plateaus, involving predominately $\alpha 5 \beta 1$ integrin-FN adhesion complexes, are diminished and the contribution from opposing nonspecific interactions is increased. While the underlying mechanisms are unclear, it is conceivable that the voltage pulses cause desorption of FN or modify its conformation. However, we suggest that a direct effect on the cell membrane is also likely, as evidenced by a decrease in the plateau force combined with an increase in the detachment length [Figs. 5(c), 5(d), 6(c), and $6(d)$ ]. Plateau interactions occur due to binding of cell surface molecules that have weak, or absent, physical linkages with internal cytoskeletal components, resulting in dislocation of the binding complex followed by extraction of lipids that form a tube, or membrane tether, as the cell moves away from the point of adhesion. The force of the membrane tether (plateau force) does not reflect the strength of the adhesion complex per se but is described by lipid membrane properties such as membrane bending rigidity and dimension of the tether. $^{38,39}$ A decrease in tether force combined with its ability to extend for longer distances indicates a change or weakening of cell membrane mechanical properties, which we suggest originates due to the monophasic pulses having similar threshold voltages that induce electroporation mechanisms, as described above. Changes to the lipid membrane morphology may also affect integrin receptors, e.g., their conformation or orientation, leading to lower binding probability, as observed by a decrease in the number of jumps per curve in Fig. 6 . Hence, implications of the effects of pulsed stimulation on cells at electrode surfaces, namely, decreases in cell adhesion caused by possible disruption of the cell membrane are an important consideration. On the other hand, by combining different types of stimulation waveforms, such as a series of constant and pulsed stimulation with optimized threshold parameters, it may also be possible to tune cell interactions and adhesion, which is of interest for cell culture technologies and biomaterials.

\section{ACKNOWLEDGMENTS}

The authors are grateful for the support of the Chinese Scholarship Council and continued financial support of the Australian Research Council under the Australian Research Fellowship (DP110104359) of Michael Higgins. Funding from the Australian Research Council Centre of Excellence Scheme (Project No. CE 140100012) is gratefully acknowledged. The authors would like to thank the Australian National Nanofabrication Facility-Materials node for equipment use.

${ }^{1}$ J. Y. Wong, R. Langer, and D. E. Ingber, Proc. Natl. Acad. Sci. 91, 3201 (1994).

${ }^{2}$ A. Kotwal and C. E. Schmidt, Biomaterials 22, 1055 (2001).

${ }^{3}$ K. Svennersten, M. H. Bolin, E. W. Jager, M. Berggren, and A. Richter-Dahlfors, Biomaterials 30, 6257 (2009).

${ }^{4}$ A. M. Wan, D. J. Brooks, A. Gumus, C. Fischbach, and G. G. Malliaras, Chem. Commun. 35, 5278 (2009).

${ }^{5}$ J. Liao, Y. Zhu, Z. Zhou, J. Chen, G. Tan, C. Ning, and C. Mao, Angew. Chem. 126, 13284 (2014).

${ }^{6}$ E. W. Jager, M. H. Bolin, K. Svennersten, X. Wang, A. Richter-Dahlfors, and M. Berggren, "Electroactive surfaces based on conducting polymers for controlling cell adhesion, signaling, and proliferation," in TRANSDUCERS
2009-2009 International Solid-State Sensors, Actuators and Microsystems Conference, Denver, CO, 21-25 June 2009 (IEEE, 2009), pp. 1778-1781.

${ }^{7}$ C. Saltó, E. Saindon, M. Bolin, A. Kanciurzewska, M. Fahlman, E. W. Jager, and M. Berggren, Langmuir 24, 14133 (2008).

${ }^{8}$ K. M. Persson, R. Karlsson, K. Svennersten, S. Löffler, E. W. Jager, A. Richter-Dahlfors, P. Konradsson, and M. Berggren, Adv. Mater. 23, 4403 (2011).

${ }^{9}$ Y. Wang, M. Rouabhia, and Z. Zhang, Biochim. Biophys. Acta Gen. Subj. 1860, 1551 (2016).

${ }^{10}$ X. T. Cui and D. D. Zhou, IEEE Trans. Neural Syst. Rehabil. Eng. 15, 502 (2007).

${ }^{11}$ X. Liu, K. J. Gilmore, S. E. Moulton, and G. G. Wallace, J. Neural Eng. 6, 065002 (2009).

${ }^{12}$ E. Stewart, N. R. Kobayashi, M. J. Higgins, A. F. Quigley, S. Jamali, S. E. Moulton, R. M. Kapsa, G. G. Wallace, and J. M. Crook, Tissue Eng. Part C Methods 21, 385 (2014).

${ }^{13}$ K. J. Gilmore et al., Biomaterials 30, 5292 (2009).

${ }^{14}$ A. F. Quigley, J. M. Razal, B. C. Thompson, S. E. Moulton, M. Kita, E. L. Kennedy, G. M. Clark, G. G. Wallace, and R. M. Kapsa, Adv. Mater. 21, 4393 (2009).

${ }^{15}$ A. K. Dubey, S. D. Gupta, and B. Basu, J. Biomed. Mater. Res. B Appl. Biomater. 98, 18 (2011).

${ }^{16}$ M. J. Higgins, S. T. McGovern, and G. G. Wallace, Langmuir 25, 3627 (2009).

${ }^{17}$ M. Marzocchi, I. Gualandi, M. Calienni, I. Zironi, E. Scavetta, G. Castellani, and B. Fraboni, ACS Appl. Mater. Interfaces 7, 17993 (2015).

${ }^{18}$ A. Gelmi, M. J. Higgins, and G. G. Wallace, Biomaterials 31, 1974 (2010).

${ }^{19}$ A. Gelmi, M. J. Higgins, and G. G. Wallace, Small 9, 393 (2013).

${ }^{20}$ A. M. Wan, R. M. Schur, C. K. Ober, C. Fischbach, D. Gourdon, and G. G. Malliaras, Adv. Mater. 24, 2501 (2012).

${ }^{21}$ P. J. Molino, Z. Yue, B. Zhang, A. Tibbens, X. Liu, R. M. Kapsa, M. J. Higgins, and G. G. Wallace, Adv. Mater. Interfaces 1, 1300122 (2014).

${ }^{22}$ J. J. Gooding, C. Wasiowych, D. Barnett, D. B. Hibbert, J. N. Barisci, and G. G. Wallace, Biosens. Bioelectron. 20, 260 (2004).

${ }^{23}$ I. Bekard and D. E. Dunstan, Soft Matter 10, 431 (2014).

${ }^{24}$ H. Potter and R. Heller, Curr. Protoc. Mol. Biol. 121, 9.3.1 (2018).

${ }^{25}$ C. M. Franz, A. Taubenberger, P. H. Puech, and D. J. Muller, Sci. STKE 2007, p15 (2007).

${ }^{26}$ J. Friedrichs, J. Helenius, and D. J. Muller, Nat. Protoc. 5, 1353 (2010).

${ }^{27}$ A. Taubenberger, D. A. Cisneros, J. Friedrichs, P. H. Puech, D. J. Muller, and C. M. Franz, Mol. Biol. Cell 18, 1634 (2007).

${ }^{28}$ P. H. Puech, K. Poole, D. Knebel, and D. J. Muller, Ultramicroscopy 106, 637 (2006).

${ }^{29}$ A. V. Taubenberger, D. W. Hutmacher, and D. J. Muller, Tissue Eng. B Rev. 20, 40 (2013).

${ }^{30}$ S. Sankaran, L. Jaatinen, J. Brinkmann, T. Zambelli, J. Vörös, and P. Jonkheijm, ACS Nano 11, 3867 (2017).

${ }^{31}$ L. Jaatinen, E. Young, J. Hyttinen, J. Vörös, T. Zambelli, and L. Demkó, Biointerphases 11, 011004 (2016).

${ }^{32}$ H. Zhang, P. J. Molino, G. G. Wallace, and M. J. Higgins, Sci. Rep. 5, 13334 (2015).

${ }^{33}$ N. Strohmeyer, M. Bharadwaj, M. Costell, R. Fässler, and D. J. Müller, Nat. Mater. 16, 1262 (2017).

${ }^{34}$ H. Zhang, Q. Gu, G. G. Wallace, and M. J. Higgins, Biointerphases 13, 041004 (2018).

${ }^{35}$ E. P. Wojcikiewicz, X. Zhang, and V. T. Moy, Biol. Proced. Online 6, 1 (2004).

${ }^{36}$ E. Sariisik, C. Popov, J. P. Müller, D. Docheva, H. Clausen-Schaumann, and M. Benoit, Biophys. J. 109, 1330 (2015).

${ }^{37}$ S. E. Moulton, J. N. Barisci, A. Bath, R. Stella, and G. G. Wallace, Electrochim. Acta 49, 4223 (2004).

${ }^{38}$ M. Sun, J. S. Graham, B. Hegedüs, F. Marga, Y. Zhang, G. Forgacs, and M. Grandbois, Biophys. J. 89, 4320 (2005).

${ }^{39}$ R. M. Hochmuth and W. D. Marcus, Biophys. J. 82, 2964 (2002).

${ }^{40}$ M. J. Higgins and G. G. Wallace, Polym. Rev. 53, 506 (2013).

${ }^{41}$ M. L. O'Grad and K. K. Parker, Langmuir 24, 316 (2008).

${ }^{42}$ See supplementary material at https://doi.org/10.1116/1.5082204 for figure showing a SCFS curve detailing the different types of interactions and parameters, including maximum de-adhesion force, de-adhesion energy, jumps and plateaus. 